\title{
Beyond US-Centered Multicultural Foundations on Race
}

\author{
James C. Jupp \\ University of Texas Rio Grande Valley \\ U. S. A. \\ Miryam Espinosa-Dulanto \\ University of Texas Rio Grande Valley \\ U. S. A.
}

\begin{abstract}
Our conceptual essay begins with the recognition of the U.S. racialized tragedy and embattled discussions on race. Within this tragedy and embattled discussion, we attempt to renew and reinvigorate authentic, dialogic, and vulnerable exchanges on race. With this focus, we critique yet further advance multicultural foundations' notions of racial identity predominant in the academy and in broader national discussions on race. Critiquing yet advancing multicultural foundations, we emphasize conceptual content from five books on race and power by Cornel West. Working through West's conceptual content, we emphasize complex and historicized identifications and relationalities as key concepts in the present moment.
\end{abstract}

KEYWORDS: race, multicultural education, cosmopolitan education, multicultural identity, ethics

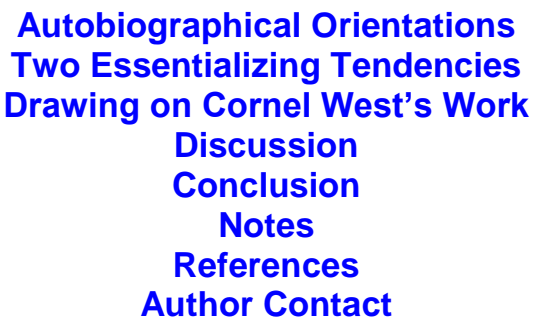

Our conceptual essay begins with recognition of the U.S. racialized tragedy and embattled discussions on race. Within this tragedy and embattled discussion, we attempt to renew and reinvigorate authentic, dialogic, and vulnerable exchanges on race. With this focus, we critique yet further advance multicultural foundations' notions of racial identity predominant in the academy and in broader national discussions on race. Critiquing yet advancing multicultural foundations, we emphasize conceptual content from five books on race and power by Cornel West. Working through West's conceptual content, we emphasize complex and historicized identifications and relationalities as key concepts in the present moment. 
The UnitedStatesian ${ }^{1}$ racial tragedy currently shows no sign of abatement. Within the academy, ways to honestly discuss race in the United States continue to be characterized by striking silences, awkward exchanges, and hostilities. On the national level, the 2016 fatal shootings of Philando Castile in St. Paul and Alton Sterling in Baton Rouge only added to other recent shootings of Black males including 12-year-old Tamir Rice in Cleveland and Tony Robinson in Madison as well as the strangulation of Eric Garner in New York, the killing of Freddie Gray in Baltimore, and the Chicago cover-up of the shooting of Laquan McDonald. Additionally, we denounce the racist terrorist acts of Dylann Roof in the Mother Emanuel A.M.E. Church in Charleston, South Carolina, which left nine people murdered, and the continued attacks on African American churches across the South. We believe that discussing race in the academy is an important component to the national discussion on race, and this essay seeks to create the conditions for continued authentic dialogue within the academy.

We mention these events to somberly recognize the ongoing violent tragedy without using these events as "stand ins" for the larger violence carried out through racialized structuring and segregation since the inception of the US. Certainly, the historic sweep of racial representation in the United States (Omi \& Winant, $1986 / 1994,2005)$ demonstrates that discursively structured racialized violence is a constant feature of U.S. society, and recent deaths are but a few more examples of direct violence against people of color in a society historically structured by White supremacy and presently organized through White privilege. Moreover, the punditry of capitalist "news" coverage in its sound bites and polemics seems only to attempt to ignore a history of White supremacy and protect White privilege in the present moment. Truly, a sign of the times is Donald Trump's election as the $45^{\text {th }}$ President of the United States. Trump's platform was advanced by a White supremacist ticket, raging anti-immigrant media, and Islamophobia. White privilege is the new final solution for all "threats." Surprisingly—much but not at all, efforts to work through or discuss race in the academy continue to elicit striking silences, un-dialogic exchanges, and new hostilities (e.g., Bergamo Conference on Curriculum Theory and Classroom Practice, 2015; Curriculum \& Pedagogy Group, 2009, 2011; Dixon et al., 2012; Malewski, 2010).

Perhaps erring in its hope for cosmopolitan interlocution (e.g., Baldwin, 1965/1998; Dussel, 2005; Freire, 1970; King, 1958/2010a, 1968/2010b; de Oliveira Andreotti, 2011, 2015; Paraskeva, 2011, 2016; West, 2004, 2014; X \& Haley, 1964/1995), our essay modestly approaches the question: In embattled racial discussions in the academy, can we learn to talk and listen to each other? Attempting to affirmatively answer this question, our conceptual essay ${ }^{2}$ develops the following contours. In the sections that come, our essay:

1. Situates ourselves as implicated in the research question and provides our autobiographical orientations with regard to the question: situating ourselves in the research, we think, is necessary as part of identity work in which the researchers' identities are always already embedded.

2. Briefly characterizes and critiques multicultural foundations so influential in the U.S. academy and, more broadly, UnitedStatesian critical 
understandings of race: this characterization, understanding the need for broad self-correction, critiques essentializing tendencies not with the intention of oppositional dismissal but with the desire to work through and further advance multicultural foundations in the hegemonic globalizing conditions of the present.

3. Provides an analytical synopsis of five books on race and power by Cornel West (1993a, 1993b, 2001, 2004, 2014) that seek to add to and deepen multicultural foundations by developing key themes, such as race as key criterion, the pitfalls of racial reasoning, the importance of self-identity work, and thinking historically: West, as explained in this essay, effectively moves discussions on race and power toward crosscultural, cosmopolitan, global-yet-local engagements that we consider important in the present.

4. Develops, through West's writings, concepts that challenge, reach back historically, yet renew educational foundation's commitments to social justice in transforming West's ideas into critical understandings of identifications and relationalities.

Our essay, in developing identifications and relationalities, moves discussions on race and power into broader contexts and articulates critical cross-cultural, cosmopolitan, and global-yet-local exchanges in order to counter hegemonic globalizing conditions in the present moment.

\section{Autobiographical Orientations}

As co-authors of the piece, we situate this essay within our autobiographies. Jim Jupp, a White middle class male from Texas and father of an interracial Latin@ family, spent 18 years as a classroom teacher working with predominantly indigenous Mexican immigrant, Latin@, and African American students in innercity public schools. In his public school teaching, Jim strove to develop critical and historically-based teaching and learning with special focus on Freirean and culturally relevant approaches to teaching and learning with his students. Miryam Espinosa-Dulanto, a Peruvian-born educational anthropologist, has spent her life committed to social justice of Latin@ and indigenous populations in Latin America and the United States. Miryam, as an activist anthropologist, currently works closely with and researches marginalized mestiza-indigenous populations within the South Georgia Latin@ diaspora and along the Eastern Texas/Mexican border. Both researchers, with experience in the Southern US and South Texas, seek to take on the critical task for authentic dialogue and racial understanding.

With these experiences and intentions in common, this article emerges from our lifelong commitment to discussions of race and racism in society, schools, and education research. Especially, this article springs from our conversation on the topic of stalled and failed discussions on race in the academy. Having attended numerous academic conferences in which discussions on race stall, fail, and 
create new hostilities (e.g., Bergamo Conference on Curriculum Theory and Classroom Practice, 2015; Curriculum \& Pedagogy Group, 2009, 2011; Dixon et al., 2012; Malewski, 2010), we advance this essay that re-theorizes multicultural foundations through the work on race and power by Cornel West with the intention of creating new generative discussions on race.

\section{Two Essentializing Tendencies}

Though impossible to detail the vast cultural production of articles, books, and, especially, textbooks on race in multicultural education ${ }^{3}$, we strategically focus on mainstream confluences in recent formulations of multicultural foundations (Banks, 2001; Bennett, 2007; Gay, 2001; Grant, 2006; Grant \& Sleeter, 2007; Tozer, Senese, \& Violas, 2009). Multicultural foundations, by definition, refers to a body of educational theory, practice, and empirical research that seeks to critically transform education across differences (e.g., race, class, gender, sexuality, ability, and other markers) in ways that advance teaching and learning for social justice. We focus on multicultural foundations because of their established position and influence in understandings of race in educational discourse, educational research, and teacher education that broadly inform the academy in the present moment. In this section, we briefly characterize multicultural foundations with the dual purposes of articulating multicultural foundations' historical location and critiquing two essentializing tendencies inherent in this work.

\section{Multicultural Foundations' Historical Location}

As Gay (2001) correctly commented, "Future analysis undoubtedly will reveal that multicultural education is very Western and American in spirit and intent" (p. 41). Our essay, supporting Appelbaum's (2002) historicized understanding of multicultural education, ties multicultural education to 1960s UnitedStatesian understandings to which Gay (2001) insightfully referred to in her handbook essay.

Influenced by intercultural and intergroup education (Banks, 2001, 2013; Grant, 2006), multicultural foundations of education "is directly linked to the early ethnic studies movement" in the United States (Banks, 2001, p. 45). From this link, multicultural foundations of education emerged in the early 1970s in the wake of U.S. civil rights movements (Banks, 2001, 2013; Grant, 2006; Howard, 2006). Emerging on the U.S. scene, multicultural education privileged UnitedStatesian understandings emphasizing "a coming together of different identity groups" (Grant, 2006, p. 10), very much following the unfolding of civil rights era movements in the United States focusing on race, class, gender, sexuality, and later intersectionality with differences. In a historical essay, Grant (2006) explains multicultural foundations' intent writ large: 
Multicultural education advocates a long comprehensive, non-patriarchal view of the history and contributions of marginalized groups to the traditional curriculum....Proponents of multicultural education continually challenge the racism and sexism in arguments that contend that achievements have come about because of, for example, Manifest Destiny. (p. 10)

Multicultural foundations of education, emphasizing UnitedStatesian historical positions and understandings, universalizes these understanding to other engagements as a model of teaching and learning on difference in education (Banks, 2001; Bennett, 2007; Gay, 2001; Grant, 2006; Grant \& Sleeter, 2007; Tozer, Senese, \& Violas, 2009). The multicultural foundations of education posit 1950s, 1960s, and 1970s UnitedStatesian civil rights struggles as the general template for understanding differences in all contexts. Particularly apparent in Banks' (2013) notion of global citizenship tacked on to previous models of multicultural education in his most recent textbook, it becomes increasingly important to critique these UnitedStatesian understandings, not to dismiss them but rather to advance relevant multicultural, cross-cultural, and cosmopolitan understandings in the historical present.

West's $(2001,2004,2014)$ writings on race and power attend to UnitedStatesian understandings of race yet situate those within historicized, crosscultural, and cosmopolitan contexts. Important in our analysis is re-historicizing and provincializing both UnitedStatesian and Anglophone-Icentered understandings of race, difference, and identity as a starting point in our discussion. In short, we believe that these discussions should situate UnitedStatesian and Anglophone understandings among other intellectual and historical resources for teaching, learning, and discussing race in academia. This re-historicizing and provincializing is especially important in our discussion and conclusion at the end of our essay.

\section{Erroneous Tendencies}

Besides identifying multicultural foundations as a UnitedStatesian and Anglophone project that is often universalized in unspoken ways, we assert that multicultural education's legacy has left us with two erroneous essentializing tendencies in the present international and intercultural moment. However, in discussing what we consider erroneous tendencies of multicultural foundations, it becomes important to state what we agree with: (a) multicultural education's commitment to social justice and (b) its rejection of White supremacy. Agreeing with these two starting points, we nonetheless understand our commitments to be worked out within specific social, institutional, and historical contexts. Important here for us is that social justice be under-determined, relational, dialogic, and subjunctive (Ellsworth, 1989, Freire, 1970; Pinar, 2011, West, 2014) rather than determined, monological, and declarative. Our position, rather than accepting universalizing intellectual models, emphasizes social justice and anti-White 
supremacist work as contextualized, pedagogically specific, and engaged in global-local contexts.

Having recognized our points of agreement, we move on to multicultural foundations' two erroneous tendencies. First, we argue that assigning fixed before/after identities is an erroneous tendency. This assigning of fixed before/after identities (very often) delineates oppressed person of color and White privilege identities prior to the multicultural intervention. After the intervention, these identities are to be followed by emancipated person of color and Whiteally/race-evasive identities. We argue against multicultural foundations' fixed before/after "conversions" not because we oppose social justice or anti-White supremacist work. To the contrary, we argue against conversions because fixed before/after interventions lack sufficient subtlety, nuance, or attention to process for actually advancing identity conscientization. Following recent breakthroughs, research on White identity conscientization emphasizes process-identities, emotional content, institutional contexts, and psychoanalytic approaches for identity change (e.g., Berchini, 2016; Borsheim-Black, 2015; Crowley, 2016; Flynn, 2015; Jupp, 2013; Jupp \& Slattery, 2010, 2012; Lensmire, 2011, 2014; Mason, 2016; Sarigianides, 2017; Tanner, 2015, 2016). Equally important, the conscientization of people of color is far from linear and requires personal supports, mentors of color, and racialized intellectual content (Anthrop-Gonzales \& de Jesus, 2006; Berry, 2012, 2014; Jennings \& Lynn, 2005; Morales, 2011; Taliaferro Baszile, 2006). Following recent research directions, we believe that discussions on racial identity must include greater attention to multiple positionalities and identity knowledge about race in discussions while, most importantly, not diluting critical structural or epistemological content on racialized oppression. Moving beyond before/after conversions, we argue that new positionalities need to be teased out, elaborated on, and recognized as part of teaching, learning, and discussion on race in the academy. In this way, richer and more complex discussions on race will better inform contextualized social action within systematic understandings of White supremacy.

Second, we argue that multicultural foundations' UnitedStatesian and Anglophone, additionally Puritanical and Manichean, opposition to Eurocentric "traditional curriculum" (Grant, 2006, p. 20) is also an erroneous essentializing tendency. We think the swap of Eurocentric traditional curriculum for 1960s revisionist histories conceals the complexity of historical relationalities required to think carefully, clearly, and historically in the present moment (e.g., Appiah, 2006; Baker, 2009; Coronil, 1998; de Sousa Santos, 2009; Dussel, 2005; Hendry, 2012; Paraskeva, 2011, 2016; West, 2004, 2014). Drawing particularly on Latin@ and Hispanophone-influenced scholars such as Fernando Coroníl (1998), Boaventura de Sousa Santos (2009), Enrique Dussell (2005), and João Paraskeva (2011, 2016), our critique of multicultural foundations, rather than dismissing U.S.-based revisionist history, drives at greater historicized understandings among collectivities within cross-cultural, cosmopolitan, and global-local contexts. Following Latin@ and Hispanophone-influenced scholars presents finer recognitions of identity group differences and ultimately offers greater ability and understanding to conjugate collective alliances in leveraging projects for social 
justice in the hegemonic globalizing conditions of the present. Of particular importance in this discussion are the notions of historical hybridity in Coroníl (1998), dialectics of transmodernity in Dussell (2005), and ecologies of knowledge in de Sousa Santos (2009) and Paraskeva $(2011,2016)$. Each of these notions presents important historicized decolonial directions that require more development.

Having identified the UnitedStatesian and Anglophone historical blind spot and erroneous essentializing tendencies of multicultural foundations, we think West's work on race and power, unheeded for the greater part in educational foundations, helps move us toward contemporary multicultural, cross-cultural, and cosmopolitan understandings needed in contemporary discussions on race in the academy.

\section{Drawing on Cornel West's Work}

Moving toward West's (1993a, 1993b, 2001, 2004, 2014) work on race and power, we drive at the purpose of articulating strategies and tactics for alliances to counter hegemony in globalizing conditions. This essay articulates four patterns consistent in West's work as a means of advancing critical understandings of race and power for deployment in the present: (a) race as key criterion, (b) the pitfalls of racial reasoning, (c) the centrality of self-identity work, and (d) thinking historically.

\section{Race as Key Criterion}

Taking on topics of race and power, West argues that race represents a key criterion for evaluating hypocrisy and progress of democratic projects in the United States and elsewhere. West's definition of race as a key criterion refers to situating race as one key indicator among others of hegemonic oppression, especially in relation to US global hegemony. In relation to cultural workers and educators laboring in the United States, West (2001) recalls that race provides "the fundamental litmus test for American democracy" (p. xix). West (2001) continues:

Yet the fundamental litmus test for American democracy-its economy, government, criminal justice system, education, mass media, and cultureremains: how broad and intense are the arbitrary powers used and deployed against black people. (p. xix)

West recognizes, nonetheless, that race not serve as exclusive focus to exclude other questions of progressive-critical alliances. For West (1993b), race represents a key criterion yet certainly not the exclusive criterion in a broader critical-progressive project that, ultimately, combats postmodern nihilisms, fights economic imperialism, and recognizes the increasing wealth gap, yet promotes "the flowering and flourishing of individuality under the conditions of democracy" 
(p. 32). In West's vision, race is central but must attend to a broader critical project that necessarily includes, as examples, Marxian and feminist attentions to indigenous understandings and cosmologies, gay and lesbian rights, and religious equalities. For West, privileging exclusive racial reasoning over other social justice concerns damages and, ultimately, imperils a broad, inclusive, democratic, and critical project, and it dangerously re-centers racialized patriarchal and homophobic understandings. We think that, behind racialized silences and inability to engage in discussions on race, sometimes there lies a hypermasculinized patriarchy and call for order around single-criterion understandings.

\section{The Pitfalls of Racial Reasoning}

Racial reasoning, according to West (1993b, 2001), demonstrates patriarchal, homophobic, and masculine nationalist logic that silences women, gays, and other social solidarity projects through its exclusive call-to-order around race. Racial reasoning, as understood by West (2001), refers to privileging race over other social justice concerns.

As case study in racial reasoning, West (2001) narrates the case of Supreme Court Judge Clarence Thomas's nomination. In October 1991, a 35-yearold (Black female) law professor, Anita Hill, testified in front of the U.S. Senate Judiciary Committee about sexual harassment she had suffered while working under Clarence Thomas at the Equal Employment Opportunity Commission (EEOC). Although both of them were from the same racial background, Hill's gender played a key role as she voiced issues regarding sexual harassment in the workplace. Hill was torn apart by the committee as well as by elements of the press and general public; she was described as "a little bit nutty and a little slutty." Thomas, for his part, called the entire process a "high-tech lynching." West (2001) recounts, first and foremost, that Thomas provided limited credentials for the job, yet racial reasoning functioned to foreclose complex "political discussion in black America about these hearings" (p. 35). Furthermore, West (2001) noted a stunning silence on the part of African American leadership due to racial reasoning. Rather than critiquing Thomas for his misogynist and sexist record, African American leadership remained silent and instead supported him through a consensus of silence. Elaborating more completely on racial reasoning, West (2001) explains that racial reasoning undermines complex political representation and instead inserts an exclusive masculinist and patriarchal logic that serves to silence, especially, women's issues along with gay and lesbian rights. In criticalprogressive discussions, West (1993a) argues for the need to dismantle exclusive racial reasoning and replace it with moral reasoning in which the racial struggle serves as a particular case of moral-ethical reasoning and "doing the right thing" (p. 67). West (2001) summarizes:

The fundamental aim of this undermining and dismantling is to replace racial reasoning with moral reasoning, to understand the black freedom struggle not as an affair of skin pigmentation and racial phenotype but rather as a 
matter of ethical principles and politics, and to combat the black nationalist attempt to subordinate the issues and interests of black women by linking mature black self-love and self-respect to egalitarian relations within and outside black communities. (p. 38)

Seeking an egalitarian moral-ethical position, West affirms the direction of an increasing number of scholars of color (e.g., Appiah, 2006; Hall, 2003; Sen, 2006) who refer to multicultural foundations' essentializing tendencies that seem to reproduce the static identities they purport to change. Exclusive appeals to nationalist logic that West (1993a, 1993b, 2001) calls racial reasoning frequently promote not discussions on moral reasoning, but shallow controversies and intergroup infighting focusing on who-as masculinized leader-can properly talk for whom. In short, West holds (2001) that racial reasoning, evinced in catch phrases among Whites who emphasize "playing the race card," damages moral reasoning, narrows the ability to discuss complex moral-ethical questions, and deteriorates the context for authentic democratic exchanges on race. In sum, exclusive racial reasoning debilitates authentic teaching, learning, and discussion on race in the academy.

\section{Centrality of Self-Identity Work}

Building on understandings outlined above, West's (1993b, 2004, 2014) writings on race and power emphasize the centrality of self-creation. Drawing on Elliot's (1919/1975) essay "Tradition and the Individual Talent," West (1993b) argues that tradition, especially critical educative traditions, "cannot be inherited... and must be earned by great labor" (p. 129). Like Elliot (1919/1975), West (1993b, 2014) argues that individual honor, courage, integrity, and even greatness emerge through self-identity work in critical traditions of study. Self-identity work, as West (1993b, 2004) discusses it, refers to institutionally and self-directed study in multiple traditions, which enhances agency and freedom in the face of historical boundedness, obstacles, and structural oppression. For West (1993b, 2004, 2014), self-creation, which begins institutionally in family and schools and culminates in self-study, is central to historical change, especially in democracies in which "ordinary citizens desire to take their country back from the hands of a corrupt Plutocratic imperial elite" (2004, p. 23).

Resonating with curriculum scholars' recent focus on study (Block, 2001; Pinar, 2006), West (1993a, 1993b, 2004, 2014) highlights particular educative traditions, especially an international and cosmopolitan Emersonian tradition developing "cross-cultural perspectives on understanding and respecting other traditions from around the world" (2004, p. 77). Among these self-identity work resources, West (2004) indicates Socratic self-examination, prophetic Christianity, and a cross-cultural UnitedStatesian tradition emphasizing Emerson, Whitman, Melville, Du Bois, Coltrane, Martin Luther King, Jr., C. Wright Mills, Jose Carlos Mariategui, Toni Morrison, and others. In culminating his discussion on self- 
identity work, West (2004) quotes Toni Morrison at length, emphasizing her message of love for self, other, and community:

Love. We have to embrace ourselves....That's why we're here, we have to do something nurturing in that respect, before we go. We must. It is more interesting, more complicated, more intellectually demanding to love somebody. To take care of somebody. (p. 97)

West's thinking on race and power, which identifies race as key criterion yet eschews the pitfalls of racial reasoning, focuses on self-identity work within traditions that, ultimately, strives toward a moral discourse in which, in good faith, everyone comes together to morally do "the right thing" (1993b, p. 67).

\section{Thinking Historically}

In addition to forging a good faith moral discourse highlighting historically bounded self-identity work, West (1993b, 2001, 2004, 2014) asks cultural workers and educators to think historically and work carefully within multiple intellectual traditions. Related to self-identity work outlined above, thinking historically refers to careful study in our own and others' resistant intellectual traditions not for simplistic revisionisms but rather for profound understanding of identities' social structurations and malleabilities.

In this historical thinking, West critiques promiscuous multiculturalisms sometimes found in multicultural foundations for providing but a Manichean shadow of its opposite, Eurocentrism. West, in his critique of multiculturalisms, affirms multicultural recognitions of historical injustices like racism, sexism, and heteronormativity, yet he questions oversimplified reversals seemingly required by multiculturalisms as they simplistically "contest" binary Eurocentrisms (e.g., Bloom, 1987; Hirsch, 1988). Playing multiculturalisms against Eurocentrisms in a binary way, as West (1993b) argues, allows for theorizing a-historically "in a rather promiscuous manner" (p. 7). In particular, West (1993b) calls on cultural workers and educators to recognize historical complexities and eschew essentializing and static ideas like Eurocentrism versus multiculturalism. In order to transcend essentializing tendencies, West urges cultural workers and educators to undertake the challenging pathway of historical specificity requiring us to work and think carefully in multiple historical traditions including European and UnitedStatesian ones (Du Bois, 1903/2005; West, 1989). Most importantly, West (2004) teaches that, moving beyond essentialized revisionisms, cultural workers and educators refuse the ahistorical narratives that "simply flip the script and tell new lies about ourselves" (p. 15). Multiculturalisms, like the ones sometimes found in multicultural foundations, release us from careful thinking about historical relationships both inside and beyond Europe, which suggest that we might need both European traditions and multicultural, cross-cultural, and cosmopolitan understandings of other cosmologies and traditions. 
Thinking historically, says West (1993b), recognizes that Europe and its successor, the United States, present a complex hybridity of cultural confluences rather than simplistic oppositions (Coroníl, 1998; de Sousa Santos, 2009; Dussel, 2005; Sen, 2006). Cultural workers and educators need to recognize that Europe and the United States do not represent the beginning of oppression nor singular monolithic oppressors as multiculturalisms sometimes suggest. Instead, as West (1993a, 1993b) argues, cultural workers and educators should understand that European-UnitedStatesian oppressions provide historically bounded and changeable conditions of oppression as do other historically bounded examples such as the Roman or Ethiopian Amharic traditions previously holding hegemonic positions in the world. Moving beyond understandings of Europe and its successor as monolithic oppressors requires careful discernment in reading historical traditions for crimes and hypocrisies along with radical reappraisals of gifts and progressive resources provided by multiple and paradoxical historical traditions (e.g., Appiah, 2006, Baker, 2009; Connell, 2007; Coronil, 1998; de Sousa Santos, 2009; Dussel, 2005; Paraskeva, 2011; Pinar, 2013; West, 2004).

For example, critical intelligence, as West (1993a, 1993b) highlights, represents one resource and gift clearly exemplified in European-UnitedStatesian traditions allowing for continuous critique of illegitimate forms of authority especially as taken up by civil rights movements in the United States during the 1950s, 60s, and 70s. Only through thinking historically, says West (1993a, 1993b), can cultural workers and educators approach multiple and paradoxical traditions, not in terms of simplistic Manichean reversals that see only binary positionalities, but rather in careful, discerning, and hopeful ways that historically reappraise traditions as potential resources to be worked on and worked through.

\section{Discussion}

West's thinking, as it identifies race as a key criterion, eschews the exclusivity of racial reasoning, emphasizes self-identity work, and asks cultural workers and educators to think historically, and begins to remediate multicultural foundations of education's erroneous tendencies. Instead of the U.S. multicultural foundations, this essay works through West's ideas (1993a, 1993b, 2001, 2004, 2014) breaking new ground reconceptualizing identities with identifications and relationalities that move toward "a new politics of cultural difference" (1993b, p. 4) in educational foundations that simultaneously renew old critical commitments yet move toward local, national, and global progressive alliances.

\section{Identifications}

Identifications, by way of definition, refer to narrative processes through which historically and socially mediated "selves" emerge over time within structuring contexts that recognize race, class, gender, sexual orientation, religion, 
ability, and other differences. Identifications, in relation to West's work on race and power, identify race as a key criterion for social justice work yet eschew the pitfalls of exclusive racial reasoning.

Identifications, working through erroneous essentializing tendencies, assume identity to be social and historical activities. Understood as social and historical activities, identifications assert West's critical intelligence taking antiuniversalist and subversive directions. As anti-universalist, identifications critique both right-appropriated ahistorical and essentialized "individuals" as well as leftappropriated masculinist and patriarchal identities that unproblematically equate "spokesmen" to their social history. Rather than "individuals" or "spokesmen" leaders, identifications work through notions of process, coming-to-know, intraand inter-group dialogue, and vulnerability that listen as well as proclaim injustices and structural inequalities. Requiring critical intelligence in critiquing facile right and left identity appropriations, identifications attend to recognitions of lived experiences within structuring contexts and protect them from the erroneous essentialisms promulgated in facile ways on left-right political continuums. As subversive, identifications seek to destabilize fixed, static, and essentialized identity pre-packaging such as facile "liberated subjects" or simplistic "white allies/race-evasive" identities. Instead, identifications provide increased racecognizance and cross-cultural engagement in historically-mediated differences and not-ever-quite-resolved questioning and examination (Butler, 1990/1999; Hall, 2003, 2004; Wang, 2004). Conceptually, identifications might include but ultimately supersede multicultural foundations' erroneous tendencies outlined and critiqued above in that they seek to articulate narrative processes of becoming within social and historical structuring.

Identifications, superseding erroneous tendencies, focus on how identities emerge narratively within historically and socially structuring contexts (Hall, 2003, 2004; West, 2001, 2004). Identifications, articulating narratively developing identities, recognize that structuring contexts call identities into being. Nonetheless, identifications emphasize that identities emerge through narrative processes of self-identity work within structured contexts. Self-identity work, in relation to identifications and structuring contexts, illuminates subjects' narrative processes of interaction, elaboration, and engagement with educative and cultural resources. Important among these structuring contexts are race, class, gender, sexual orientation, religion, ability, and more that mark identifications' power asymmetries; nonetheless, structurations are not an essentializing fixity. Identifications understand boundedness and its importance in day-to-day practices, constructed spaces, social interactions, and social justice projects especially as projects relate to assigned boundedness like race. Important in the notion of identification is subjectivities' identity creativity that works within boundedness to differently position self and others in ways that work against the grain of established boundedness. 


\section{Relationalities}

Relationalities, by way of definition, refer to identifications' relations with otherness, historical structures and intersections, and historical traditions. Relationalities, in West's work on race and power, emphasize the centrality of selfidentity work through study in historical traditions and his notion of thinking historically.

First, relationalities emphasize otherness required in race. Race, as deeply embedded in historical relations of otherness, requires understandings of race as representational and co-performed in an historical present. Race, if understood as representational and co-performed, requires understanding race as relational set of phenomena embedded in power asymmetries and attendant to violence, especially in relation to people of color. Race, if understood as relational otherness, cannot exist in isolation from its historically located relational structuring of oppression, power, and privilege. In this way, whiteness and racial otherness are inextricably bound such that whiteness as hegemonic center, for example, cannot be understood in isolation, and white identifications represent, paradoxically, a shared project with racial others' identifications that requires mutual and critical "undoing." McCarthy (2003), in relation to whiteness and racial identity, describes this historically contingent and unstable relationality: "This essay cannot properly understand white identity or whiteness by focusing singularly on white people, assuming a necessary or self-evident unity of whiteness that defines Euro-Americans as a singular group" (p. 133). As other recent work on whiteness indicates (Jupp, 2013; Jupp \& Slattery, 2010, 2012; Lensmire, 2011, 2014; Miele, 2011a, 2011b), white identifications represent, constitute, and perform a complex, unstable, and at times ambivalent relationality with racial otherness that includes but cannot be singularly reduced to privilege in every analysis. Paradoxically, working against the grain of hegemonic White supremacy, we understand race's relationality with otherness as radically contingent and under-determined, and this essay identifies the critical-progressive task, along the lines of West (1993a), as redefining relations that might developmentally include or require discussions of ethnic nationalist logic yet should eschew exclusive overdetermined racial reasoning (West, 1993b, 2001). The deployment of ethnic nationalist logic, in avoiding overdetermined racial reasoning, needs to exercise the continual use and development of critical intelligence in working through racial discussions in the academy.

Second, relationalities, rather than focusing on group identities and spokesmen, emphasize identifications' relations with structures and intersections. Following West's (1993b; 2001) caveat on "the pitfalls of racial reasoning" (2001, p. 21), relational structures and intersections allow for greater complexity of identifications yet seek, through uses of critical intelligence and self-identity work, identifications that signify "against the grain" (1993b, p. 67). Such an exercise of critical intelligence and self-identity work takes race as key criterion for evaluation, not for identifying who can authentically be a spokesman for whom. Rather, the 
exercise of critical intelligence values risks taken and generosity extended in creating conditions for truth telling in relational, dialogical, and pedagogical spaces. While recognizing power asymmetries and violences committed by Whites against people of color and critiquing White privilege, nonetheless, relational, dialogical, and pedagogical spaces need to be made that take risks so that people can say what is on their minds in teaching, learning, and discussions on race in the academy. Following West's (1993a, 1993b, 2001, 2004, 2014) work on race and power, the notion of relationalities recognizes and emphasizes identifications' relations with asymmetric power structures and intersections in greater complexity and thereby works against the grain to "recast, redefine, and revise the very notions of 'modernity,' 'mainstream,' 'margins,' 'difference,' and 'otherness"' ( $p$. 1993a, p. 31).

Third, relationalities value, as educatively ideal, profound study (Block, 2001; Pinar, 2006; West, 2004, 2014) in multiple and interrelated historical traditions, not Procrustean "frameworks" too often related with US graduate school dissertation production. Our position emphasizes study in multiple historical traditions including European and UnitedStatesian ones, yet we strongly push beyond Eurocentric, UnitedStatesian, and Anglophone resources identifying and reworking alter-traditions currently eclipsed in epistemicides (De Sousa Santos, 2009; Paraskeva, 2011, 2016). Relationalities with multiple historical traditions value always problematic cross-cultural and cosmopolitan identifications within complex historical horizons that understand racialized injustices and inequalities but are not reduced to essentialized understandings of identity.

Examples of working in multiple historical traditions reach back genealogically yet drive forward toward critical and not-necessarily-"Western" humanistic ideals. Darío's (1888/1996) literary creativity, which engages Greek Idealism, Shakespeare's muses, Latin American indigenous history, and Marxian class critique, provides a trajectory for Latin American aesthetic modernist traditions (e.g., García Márquez, 1967/1992; Neruda, 1950/1997; Mistral, 1924/1971; Paz, 1948/1987) that dialectically deploy aesthetics for specific historical, social, and political interventions and renewed understandings. Gandhi's (1927/1987) intellectual production, which takes up Hindu religious resources and practices alongside Christian and English common law traditions, provides a trajectory for traditions of ecumenical solidarity and historically contextualized activisms (e.g., King, 1958/2010a; Hahn, 1995; Malewski, 2011a, $2011 b)$ in the face of oppression. Suzuki's (1958/1998) cross-cultural writings, generating texts in which Buddhism, Christianity, and European traditions communicate, provide for a tradition of dialogue between East and West (e.g., Ikeda, 2006; Watts, 1966/1989; Wang, 2004). Du Bois (1903/1995), drawing on African-American spirituals, European phenomenology, and U.S. pragmatism which he helped articulate, provides a trajectory for a tradition of activists, authors, and writers forming the Harlem Renaissance and beyond (e.g., Hughes, 1959/1990; Neale Hurston, 1937/2006; Wright, 1937/2008; X \& Haley, 1964/1999). Truth's (1851) provocations and Mill and Mill's (1970) treatise on sexual equality reflected, constituted, and helped drive enormous production of intellectual critique on gender and gender equality (e.g., Beauvoir, 1949/2009; Stanton, 1848/2015; 
Friedan, 1963), which intersects both in the UnitedStatesian and international contexts with race and indigeneity (e.g., Barrios de Chungara \& Viezzer, 1978; Menchú \& Burgos, 1985; Wells, 1892/2015) in addition to sexuality (e.g., Butler, 1990/1999; Genet, 1949/2004; Ginsberg, 1956/1973).

Relationalities with multiple historical traditions seem sorely needed for providing resources for creative identifications and greater cross-cultural comprehension that avoids multicultural education's monolithic often unspoken UnitedStatesian and Anglophone historical location and erroneous essentializing tendencies. From the examples above, an outline of not-necessarily-"Western" yet humanistic cultural resources for self-identity work and associated moralethical becoming emerges, which values careful study, genealogical historical thinking, cross-cultural exchange, and tensions between historical-social and transcendent moral-ethical truth telling. Such an approach, grounded in study, self-creation, and thinking historically within multiple traditions, contrasts with reductionist-yet-battling categorical "frameworks" typical of university work in the present. Our work here, which drives at historicized, cross-cultural, and cosmopolitan understandings, avoids intellectual work that simply wheels in a "framework" to sector off reductionist, fundamentalist, and idealized "epistemologies" for safe yet divisive academic silos. We believe that resorting to frameworks is part not of dialogic exchanges, but of misunderstandings, selfrighteousness, and ultimately lagoons of silence on race.

\section{Conclusion}

In closing, we return to our question: Can we learn to talk and listen to each other about race? In this essay, we have developed the position that erroneous essentializing tendencies, exemplified and lingering in predominant multicultural foundations, have provided a specific UnitedStatesian and Anglophone fixity in embattled discussions on race, which might, rather than improving the discussion, create truncated, awkward, shallow, Manichean, and Puritanical exchanges that simultaneously disavow yet recreate racist identity structurations. In order to unfix and unsettle erroneous tendencies, we have advanced West's multicultural, crosscultural, and cosmopolitan understandings not to dismiss multicultural education's focus on race and social justice but rather to better situate and advance a complex study and discussion on race under conditions of globalizing hegemony in the present moment.

Conversations on race, too often exemplifying erroneous essentializing tendencies, privilege narrow UnitedStatesian and Anglophone understandings and at times advance a simplistic swap of UnitedStatesian positions for essentializing critical revisionism and reduction that ignore traditions of cross-cultural and cosmopolitan exchanges. In advancing our reading of West's work on race and power, we drive at un-fixing and unsettling conclusions from a previous, necessary at that time, era of multicultural foundations without dismissing those conclusions. Rather, we have worked through a critique with the intentions of advancing 
multicultural, cross-cultural, and cosmopolitan understandings that refocus on nonessentializing identifications and relationalities in order to combat hegemonic globalization in the present moment.

In advancing these multicultural, cross-cultural, and cosmopolitan concepts, we critique multicultural education's essentializing erroneous tendencies. Our critique, especially important in academy, seeks to revise multicultural education's insistence on masculinized spokesmen toward more nuanced and subtle critical exchanges in which feminist, cross-cultural authenticity, vulnerability, generosity, alliances, and organizing might find a home over the now standard polemics (West, 2014). We understand, nonetheless, that the uncritical advance of multicultural foundations, with its residue of the US-based movements and their "masculinized" spokesmen, remains attractive to many professors (and their students) who wish to uncritically relive the past civil rights movements in the academy of the present. Nonetheless, we insist that the task at hand, far from reliving the past through the incantation of a newer and more "radical" research framework typical of predominantly transmissive thinking in academia, lies in creating the conditions for broad participation in race cognizant yet non-essentializing understandings and new related social movements for fighting the harrowing spectre of fascism in the Trump administration. By drawing on West in articulating identifications and relationalities, we attempt to provide conditions that might ignite broader multicultural, cross-cultural, and cosmopolitan engagement that takes on the more onerous task of recreating broad-based social movements in the present. In our vision, discussions of race in the academy play a key role.

Within these contemporary conditions, we argue that the context has moved, is different, and demands careful cross-cultural, cosmopolitan, global-yetlocal understandings of race and identity for supple and movable alliance politics and solidarity in the face of rising fascisms in the United States and around the world. We argue that identifications and relationalities, linked to and determined to advance multicultural education in the present, drive more clearly at alliances along a number of identities, contexts, and issues in which cultural workers and educators might work together. What do we need, then, in order to engage in race discussions? This essay drives at greater alliances, work on race, culture, and grassroots democracy that emphasizes identifications and relationalities outlined above. Identifications and relationalities allow for more ample discussions of racialized and other identities, avoid assigning essentialized identities and conversions from the outset, direct us morally and ethically inward toward careful self-identity study, and require us to think historically in multicultural, cross-cultural, and cosmopolitan contexts.

\section{Notes}

1. UnitedStatesian, emerging from estadounidense in Latin American traditions, recognizes "American" as pertaining to all territories from the Bering Strait to Patagonia as in las Américas. Diminishing colonizing understandings that 
equate "America" to the United States, this essay deploys UnitedStatesian instead of American, nonetheless leaving "American" - though we disagree with its usage - in quoted material and titles in references. Our intent is not accidental in using and developing the term UnitedStatesian, as it suggests a re-provincialization of the United States and its influences, especially as it relates to UnitedStatesian and Anglophone multicultural foundations of education.

2. Using the conceptual essay as research methodology (Baldwin, 1962/1998; Careaga Medina, 1972), we emphasize the centrality of the conceptual essay in educational traditions (e.g., Baldwin, 1962/1998; Dewey 1904; Freire, 1970, 1992; Vasconcelos, 1925/1997). As research methodology, the conceptual essay allows for process-oriented research and argumentation organized around a topic of inquiry. The conceptual essay, as taken up here, considers the following texts as "data": personal teaching experience, experience working with preservice teachers, experience working with professional teachers and graduate students, and relevant philosophical and multicultural writing. Let this note stand in the place in what is vulgarly known as "research methodology," a token for those who insist on methods-centered human science understandings.

3. For a partial list of more than 40 textbooks on multicultural education between 1980 and 2003, see Chang (2003) in our references.

\section{References}

Anthrop-González, R., \& De Jesús, A. (2006). Toward a theory of critical care in urban small school reform: Examining structures and pedagogies of caring in two Latino community-based schools. International Journal of Qualitative Studies in Education, 19, 409-433.

Appelbaum, P. (2002). Multicultural and diversity education: A reference handbook. Santa Barbara, CA: ABC-CLIO.

Appiah, K. A. (2006). Cosmopolitanism: Ethics in a world of strangers. New York, NY: Norton.

Baker, B. (2009). Borders, belonging, beyond: New curriculum history. In B. Baker (Ed.) New curriculum history (pp. ix-xxxv). Rotterdam, Netherlands: Sense.

Baldwin, J. (1998). The creative process. In T. Morrison (Ed.), Collected essays (pp. 669-672). New York, NY: The Library of America. (Original work published 1962)

Baldwin, J. (1998). A talk to teachers. In T. Morrison (Ed.), Collected essays (pp. 678-686). New York, NY: The Library of America. (Original work published 1963)

Banks, J. A. (2013). An introduction to multicultural education (5 $5^{\text {th }}$ ed.). San 
Francisco, CA: Jossey Bass.

Banks, J. A. (2001). Multicultural education: Historical development, dimensions, and practice. In J. A. Banks \& C. A. McGee Banks, Handbook of research on multicultural education (pp. 3-24). San Francisco, CA: Jossey Bass.

Barrios de Chungara, D., \& Viezzer, M. (1978). Let me speak! (Trans. V. Ortiz). New York, NY: Monthly Review Press.

Beauvoir, S. (2009). The second sex (Trans. C. Borde \& S.Malovany-Chavallier). New York, NY: Vintage. (Original work published 1949)

Bennett, C. (2007). Comprehensive multicultural education: Theory and practice (6th ed.). Boston, MA: Allyn and Bacon.

Bergamo Conference on Curriculum Theory and Classroom Practice. (2015, October). Why is Bergamo so white? Program document of the annual meeting of the Bergamo Conference on Curriculum Theory and Classroom Practice. Dayton, $\mathrm{OH}$.

Berchini, C. (2016). Structuring contexts: Pathways toward un-obstructing raceconsciousness. International Journal of Qualitative Studies in Education, 29, 1030-1044.

Berry, T. R. (2012). Father, daughter, schooling: Curriculum theorizing from a critical race feminist perspective. In S. Hughes \& T. R. Berry (Eds.), The evolving significance of race: Living, learning, \& teaching (pp. 17-21). New York, NY: Peter Lang.

Berry, T. R. (2014). Internationalization, internalization, and intersectionality of identity. Journal of Curriculum Theorizing, 30, 4-14.

Block, A. (2001). Essay on ethics and curriculum. Unpublished essay.

Bloom, A. (1987). The closing of the American mind. New York, NY: Touchstone.

Borsheim-Black, C. (2015). "It's pretty much White": Challenges and opportunities of an antiracist approach to literature instruction in a multilayered context. Research in the Teaching of English, 49, 407-429.

Butler, J. (1999). Gender trouble: Feminism and the subversion of identity. New York, NY: Routledge. (Original work published 1990)

Careaga Medina, G. (1972). Intelectuales, poder, y revolución. Mexico City, Mexico: Ediciones Oceano, SA.

Chang, H. (2003). Multicultural education for global citizenship: A textbook analysis. Electronic Magazine of Multicultural Education, 5(2), 1-9. Retrieved from https://www.dropbox.com/sh/32gnhv01ctg8nkk/AAAB2ra SkNDJtQR0I9tfqUn_a/2003-v5n2.GlobalEducation?dl=0\&preview= Chang.pdf

Connell, R. (2007). The northern theory of globalization. Sociological Theory, 25, 368-385.

Coronil, F. (1998). Más allá del occidentalismo: Hacia categorías geohistóricas no- 
imperialistas. In E. Mendieta's (Ed.) Teorías sin disciplina: Latinoamericanismo, poscolonialidad, y globalización en debate (pp. 121196). Mexico City, Mexico: Editorial Porrúa.

Crowley, R. (2016). Transgressive and negotiated White racial knowledge. International Journal of Qualitative Studies in Education, 29, 1016-2028.

Curriculum \& Pedagogy Group. (2009, October). Town Hall Meeting. Program document of the annual meeting of the Curriculum \& Pedagogy Group in Atlanta, GA.

Curriculum \& Pedagogy Group. (2011, October). Town Hall Meeting. Program document of the annual meeting of the Curriculum \& Pedagogy Group in Akron, $\mathrm{OH}$.

Darío, R. (1996). Azul. Mexico City, Mexico: Editores Mexicanos. (Original work published 1888)

de Oliveira Andreotti, V. (2015, August). Ethics, interdependence, and global change: Imagining global citizenship education otherwise. Paper presented at ICP 2015: 12th Convention of the International Confederation of Principals, Helsinki, Finland.

de Oliveira Andereotti, V. (2011). (Towards) decoloniality and diversity in global citizenship education. Globalisation, Societies, and Education, 9, 381-387.

de Sousa Santos, B. (2009). A non-occidental West? Learned ignorance and ecology of knowledge. Theory, Culture, \& Society, 26, 7-8, 103-125.

Dewey, J. (1904). The educational situation. Chicago, IL: University of Chicago Press.

Dixon, A. D., Donner, J. K., Gilborn, D., Ladson-Billings, G. J., Solórzano, D. G., \& Tate, W. F. (2012, April). What Derrick Bell knew: The legacy of critical race theory on educational scholarship. Symposium conducted at the Annual Meeting of the American Association of Educational Research, Vancouver, Canada.

Du Bois, W. E. B. (1995). Souls of black folks. New York, NY: Signet Classics. (Original work published 1903)

Dussel, E. (2005). 13 Transmodernidad e interculturalidad. Interpretación desde la filosofía de la liberación. Retrieved from http:/www.afyl.org/ transmodernidadeinterculturalidad.pdf

Elliot, T. S. (1975). Tradition and the individual talent. In F. Kermode Selected prose of T.S. Elliot (pp. 37-44). New York, NY: Farrar, Straus \& Giroux.

Ellsworth, E. (1989). Why doesn't this feel empowering? Working through the repressive myths of critical pedagogy. Harvard Educational Review, 59, 297-324.

Flynn, J. E. (2015). What fatigue: Naming the challenge of moving from an individual to a systemic understanding of race. Multicultural Perspectives, $17,115-124$. 
Freire, P. (1992). The pedagogy of hope. New York, NY: Continuum.

Friere, P. (1970). The pedagogy of the oppressed. New York, NY: Continuum.

Friedan, B. (1963). The feminine mystique. New York, NY: WW Norton \& Company.

Gandhi, M. (1987). Lo que yo creo. Mérida, Mexico: Editorial Dante. (Original work published 1927)

García Márquez, G. (1992). Cien años de soledad. Mexico City, Mexico: Editorial Diana.

Gay, G. (2001). Curriculum theory and multicultural education. In J.A. Banks \& C.A. McGee Banks (Eds.), Handbook of research on multicultural education (pp. 25-43). San Francisco, CA: Jossey Bass.

Genet, J. (2004). The thief's journal. Paris, France: The Olympia Press. (Original work published 1949)

Ginsberg, A. (1973). America. In The Norton anthology of American poetry (pp. 1126-1128). New York, NY: W. W. Norton \& Company.

Grant, C. (2006, June). The evolution of multicultural education in the United States: A journey for human rights and social justice. Paper presented at the annual meeting of the International Association of Intercultural Education in Verona, Italy 2006. Retrieved from http://www.iaie.org/ download/turin_paper_grant.pdf

Grant, C., \& Sleeter, C. E. (2007). Turning on learning: Five approaches for multicultural teaching plans for race, class, gender, and disability (4th ed.). San Francisco, CA: Jossey-Bass.

Hahn, N. T. (1995). Living Buddha, living Christ. New York, NY: Riverhead Books.

Hall, S. (2004). New ethnicities. In D.Morley \& K.H. Chen (Eds.), Stuart Hall: Critical dialogues cultural studies (pp. 441-449). New York, NY: Routledge.

Hall, S. (2003). Introduction: Who needs identity? In S. Hall \& P. du Gay, Questions of cultural identity (pp. 1-17). London, United Kingdom: Sage.

Hirsch, E. D. (1988). Cultural literacy: What every American needs to know. New York, NY: Vintage.

Hendry, P. (2012, October). Creating a New Eden: The Ursuline Mission of spiritual universalism in French colonial Louisiana. Paper presentation at the annual meeting of the Curriculum \& Pedagogy Group in New Orleans, LA.

Howard, G. (2006). We can't teach what we don't know: White teachers multiracial schools ( $2^{\text {nd }}$ ed.). New York, NY: Teachers College Press.

Hughes, L. (1990). Selected poems of Langston Hughes. New York, NY: Vintage Books. (Original work published 1959)

Hurston, Z. N. (2006). Their eyes were watching God. New York, NY: Harper Perennial Classics. (Original work published 1937) 
Ikeda, D. (2006). A new era of the people: Forging global networks of robust individuals. Tokyo, Japan: The Soka Gakkai.

Jennings, M. E., \& Lynn, M. (2005). The house that race built: Critical pedagogy, African American education, and the reconceptualization of critical race pedagogy. Educational Foundations, 19, 15-32.

Jupp, J. C. (2013). Becoming teacher of inner-city students: Life histories and teacher stories of committed inner-city teachers. Boston, MA: Sense Publishers.

Jupp, J. C., \& Slattery, P. (2010). Committed White male teachers and Identifications: Toward creative identifications and a "second-wave" of White identity studies. Curriculum Inquiry, 40, 454-474.

Jupp, J. C., \& Slattery, P. (2012). Becoming teacher of inner-city students: Identification and curriculum wisdom of committed White male teachers. Urban Education, 47, 280-311.

King, M. L. (2010a). Stride towards freedom: The Montgomery story. Boston, MA: Beacon. (Original work published 1958.)

King, M. L. (2010b). Where do we go from here: Chaos or community? Boston, MA: Beacon. (Original work published 1968.)

Lensmire, T. (2011). Laughing White men. Journal of Curriculum Theorizing 27(3), 102-116.

Lensmire, T. (2014). White men's racial others. Teachers College Record, 116, 1-32.

Malewski, E. (2010). Introduction: Proliferating curriculum. In E. Malewski (Ed). Curriculum studies handbook: The next moment (pp. 1-40). New York, NY: Routledge.

Malewski, E. (2011a, October). Part I: Why Gandhi now? A raced and sexed autoethnographic reading of the Mahatma's life. Paper presentation at the annual meeting of the Curriculum \& Pedagogy Group in Akron, $\mathrm{OH}$.

Malewski, E. (2011b, October). Part II: Why Gandhi now? Complicity and the implications of Gandhi's life for curriculum studies. Paper presentation at the annual meeting of the Curriculum \& Pedagogy Group in Akron, $\mathrm{OH}$.

Mason, A. M. (2016). Taking time, breaking codes: Moments in White teacher candidates' exploration of racism and teacher identity. International Journal of Qualitative Studies in Education, 29, 145-158.

McCarthy, C. (2003). Contradictions of power and identity: Whiteness studies and the call of teacher education. The International Journal of Qualitative Studies in Education 16,127-133.

Menchú, R., \& Burgos, E. (1985). Me llamo Rigoberta Menchú y así me nació la conciencia. Mexico City, Mexico: Siglo XXI Editores.

Miele, A. (2011a). Complicating whiteness: Identifications of veteran White 
teachers in multicultural settings. (Unpublished doctoral dissertation). San Francisco State University, San Francisco, CA.

Miele, A. (2011b). Whiteness as relational phenomena: Literature review. Unpublished manuscript.

Mill, J. S., \& Mill, H. T. (1970). Essays on sex equality (A.S. Rossi, Ed.). Chicago, IL: The University of Chicago Press.

Mistral, G. (1971). Lecturas para mujeres. Mexico City, Mexico: Porrúa. (Original work published 1924)

Morales, A. (2011). Factors that foster Latina, English Language Learner, nontraditional student resilience in higher education and their persistence in teacher education (Unpublished doctoral dissertation). Kansas State University, Manhattan, KS.

Neruda, P. (1997). Canto general. In R. Alberti (Ed.), Antología poética. Mexico City, Mexico::Planeta Mexicana. (Original work published 1950)

Omi, M., \& Winant, H. (1994). Racial formation in the United States: From the 1960 s to the 1990s ( $2^{\text {nd }}$ ed). New York, NY: Routledge. (Original work published 1986)

Omi, M., \& Winant, H. (2005). The theoretical status of the concept of race. In C. McCarthy, W. Crichlow, G. Dimitriadis, \& N. Dolby (Eds.), Race, identity and representation in education ( $2^{\text {nd }}$ ed.) (pp. 3-11). New York, NY: Routledge.

Paraskeva, J. (2011). Conflicts in curriculum theory: Challenging hegemonic epistemologies. New York, NY: Palgrave Macmillan.

Paraskeva, J. (2016). Curriculum epistemicide: Toward an itinerant curriculum theory. New York, NY: Routledge.

Paz, O. (1987). El laberinto de la soledad. Mexico City, Mexico: El Fondo de Cultura Económica. (Original work published 1948)

Pinar, W. F. (2011). Multiculturalism, nationalism, cosmopolitanism. The character of curriculum studies: Bildung, currere, and recurring question of the subject (pp. 49-62). New York, NY: Palgrave-MacMillan.

Pinar, W. F. (2006). The problem of curriculum and pedagogy. The synoptic text today and other essays: Curriculum development after the reconceptualization (pp. 109-120). New York, NY: Peter Lang.

Pinar, W. F. (2013). Curriculum studies in the United States: Present circumstances, intellectual histories. New York, NY: Palgrave Macmillan.

Sarigianides, S. T. (2017). Coerced loss and ambivalent preservation: Racial melancholia in American Born Chinese. Educational Theory, 67, 37-49.

Sen, A. (2006). Identity and violence. New York, NY: Norton.

Stanton, E. C. (2015). Seneca Falls keynote address. Retrieved from http://www.greatamericandocuments.com/speeches/stanton-senecafalls.html (Original work performed 1848) 
Suzuki, D. T. (1998). Buddha of infinite light. Boston, MA: The American Buddhist Academy. (Original work published 1958)

Tanner, S. J. (2015). What the whiteness project should have been: Poetry as a collaborative vehicle for inquiry. English Journal, 104(4), 65-70.

Tanner, S. J. (2016). Accounting for whiteness through collaborative fiction. Research in Drama Education: The Journal of Applied Theatre and Performance, 21, 183-194.

Taliaferro Baszile, D. (2006). In this place where I don't quite belong: Claiming the onto-epistemological in-between. In T. R. Berry \& N. Mizelle (Eds.), From oppression to grace: Women of color dealing with Issues in academia (pp. 195-208). New York, NY: Stylus.

Tozer, S., Senese, G., \& Violas, P. (2009). School and society: Historical and contemporary perspectives (6th ed.). Boston, MA: McGraw-Hill.

Truth, S. (1851). Ain't I a woman? Retrieved from http://schools.nyc.gov/ NR/rdonlyres/E151FA9D-6017-4556-981F-CD076D731A72/0/

SecondaryTextGuideAnswerKeyAintWoman.pdf

Vasconcelos, J. (1997). La raza cósmica/The cosmic race. Baltimore, MA: Johns Hopkins University Press. (Original work published 1925)

Wang, H. (2004). The call from a stranger on a journey home: Curriculum in a third space. New York, NY: Peter Lang.

Watts, A. (1989). The book: On the taboo against knowing who you are. New York, NY: Vintage. (Original work published 1966)

Wells, I. B. (2015). Southern horrors: Lynch law in all its phases. Retrieved from http://www.gutenberg.org/files/14975/14975-h/14975-h.htm (Original work published 1892)

West, C. (2004). Democracy matters: Winning the fight against imperialism. New York, NY: Penguin Books.

West, C. (1993a). Keeping the faith: Philosophy and race in America (pp. 67-88). New York, NY: Routledge.

West, C. (1993b). Prophetic thought in postmodern times. Monroe, MA: Common Courage Press.

West, C. (2001). Race matters. New York, NY: Vintage.

West, C. (1989). The American evasion of philosophy: A genealogy of pragmatism. Madison, WI: University of Wisconsin Press.

West, C. (2014). Black prophetic fire: In dialogue with and edited by Christa Buschendorf. Boston, MA: Beacon Press.

Wright, R. (2008). Black boy. New York, NY: Harper Perennial Classics. (Original work published 1937)

X. M., \& Haley, A. (1999). The autobiography of Malcolm X. New York, NY: 
Random House. (Original work published 1964)

\section{Author Contact}

James C. Jupp: jcjupp@gmail.com

University of Texas Rio Grande Valley, One West University Blvd. Brownsville, Texas 78520, USA

Miryam Espinosa-Dulanto: miryamespinosa@gmail.com

University of Texas Rio Grande Valley, Teaching \& Learning, BMAIN 2314, One West University Blvd. Brownsville, Texas 78520, USA 